American Journal of Biochemistry and Biotechnology 5 (4): 221-225, 2009

ISSN 1553-3468

(C) 2009 Science Publications

\title{
Screening of Actinomycete Isolates from Niche Habitats in Manipur for Antibiotic Activity
}

\author{
Debananda S. Ningthoujam, Suchitra Sanasam and Salam Nimaichand \\ Microbial Biotechnology Research Laboratory, Department of Biochemistry, \\ Manipur University, Canchipur, Imphal 795003
}

\begin{abstract}
Problem statement: The exhaustion of the usual terrestrial sources and the rise of resistant pathogens dictate the search for novel actinomycetes and new antibiotics. In this context, niche habitats such as caves, pristine forests, lakes, rivers, and other wetlands, high salt environments, marine ecosystems and endophytic niches are promising targets for survey of bioactive actinomycetes. Approach: Actinomycetes were isolated from several niche habitats in Manipur, India, on selective media such as SCNA and Chitin agar with or without antibiotics. Selected isolates were subjected to antimicrobial activity screening by Kirby-Bauer method. Results: 172 lake sediment (SCNA, LS1 series), 35 lake sediment (CA, LSCH series), 120 river (NRP, NRB and..series), 39 forest (AML series), 35 cave (KC1 series), 101 salt spring (NH, N3S and .. series), 46 Shirui jungle (SJ series) and 66 Shirui hill (SH series) actinomycetes isolates were obtained. Of 99 randomly selected isolates screened, 37 had antimicrobial activities against 1 or more indicator strains: 32 against Gram positive bacteria and 8 against Gram negative bacteria; 10 actinomycete strains were antimycotic and 3 had broad-spectrum antibiotic activities. About 18 potent antibacterial, 1 anti pseudomonas, 1 exclusively antifungal and 3 broad-spectrum antimicrobial actinomycetes were chosen for further studies. Conclusion: Niche habitats in Manipur especially wetlands show great promise for discovery of bioactive actinomycetes.
\end{abstract}

Key words: Actinomycetes, niche habitats, antimicrobial activity, Manipur

\section{INTRODUCTION}

Actinomycetes are a group of Gram-positive, high $\mathrm{G}+\mathrm{C}$, filamentous bacteria. They are excellent elaborators of biotechnological products such as antibiotics, industrial enzymes and other bioactive compounds ${ }^{[6,9,11,12]}$. They, especially Streptomyces species, account for more than $70 \%$ of the total antibiotic production. However the survey of streptomyces and other common terrestrial actinomycetes is nearly exhausted. This and the rise of antibiotic-resistant pathogenic strains dictates an increasing need for the survey of unexplored and underexplored niche habitats for novel antibiotic-producing Actinomycetes strains.

Intense screening of actinobacteria especially rare actinomycetes is taking place all over the world ${ }^{[4]}$. Exploration of actinomycete diversity of Manipur ${ }^{[15,16]}$ part of the Indo-Myanmar hotspot-holds promise for isolation of biotechnologically significant strains of actinomycetes and, even, novel species. Our main objective is to survey niche habitats in Manipur for isolating promising actinomycete strains and screening them for antibiotic activities.

\section{MATERIALS AND METHODS}

Soil sampling and pretreatment: Soil samples were collected from different niche habitats of Manipur comprising of lake sediments (Loktak Lake, the largest freshwater lake in North-East India), river sediments (Nambul River), cave (Khangkhui cave in Ukhrul district), forest areas (Shirui Jungle and Shirui Lily Hills in Ukhrul district and Amamlok Hills in Imphal West district) and salt springs (Ningel and Shikhong salt springs in Thoubal district). Each collection was made from $10-15 \mathrm{~cm}$ depth of the soil ${ }^{[14]}$. These were air-dried for 1 week $^{[17]}$, crushed and sieved. The sieved soils were then used for actinomycete isolation.

Enrichment and Isolation: One gram each of the sieved soil samples was treated with $0.1 \mathrm{~g} \mathrm{CaCO}_{3}$ and incubated at an ambient temperature for about a week.

Corresponding Author: Debananda S. Ningthoujam, Microbial Biotechnology Research Laboratory, Department of Biochemistry, Manipur University, Canchipur, Imphal 795003 
It was then suspended in $99 \mathrm{~mL}$ sterile distilled water and kept in an orbital shaker at $150 \mathrm{rpm}$ for $30 \mathrm{~min}^{[5,14]}$. Serial dilution plating of the sample were performed (in duplicate) in SCNA ( $\mathrm{pH} 7.3)^{[2,5,8,13]}$ in presence or absence of $25 \mu \mathrm{g} \mathrm{mL}^{-1}$ nystatin and/or cycloheximide. Another sample from Loktak Lake was incubated in Chitin Agar $(\mathrm{pH} 7.0)^{[7,10]}$ for isolation of rare actinomycetes. The plates were incubated at $28-30^{\circ} \mathrm{C}$ for 2-3 weeks. Isolated colonies were further subcultured on SCNA plates ${ }^{[14,18]}$. Selected pure isolates were then used for antimicrobial assay.

Test organisms: The test organisms used were the Gram positive bacteria Staphylococcus aureus (MTCC 96), Micrococcus luteus (MTCC 106), Bacillus subtilis (MTCC 121) and the Gram negative bacteria Escherichia coli (MTCC 739) and Pseudomonas aeruginosa (DN1, lab isolate). The test yeast/fungus used was Candida albicans (MTCC 227) and Aspergillus niger (MTCC 1344).

Antimicrobial activity: Morphologically distinct actinomycete isolates were selected for antimicrobial activity screening against the pathogenic test organisms. This was done by using Kirby-Bauer method $^{[3]}$.

Test isolates were grown on antibiotic producing medium (GS medium) in an orbital shaker (150 rpm ambient $^{-1}$ temperature). The fermentation broths were centrifuged after 3rd, 5th and 7th day of incubation and the supernatant were used as crude antibiotic extract of the isolates.

Test pathogens were spread on the test platesNutrient Agar (NA) for bacteria and Sabouraud Agar (SA) for yeast/fungi. Sterile antibiotic discs (HiMedia, $5 \mathrm{~mm}$ diameter)-impregnated with the crude antibiotic extract of the test isolates-were transferred to the test plates and incubated for 24-48 h. The zone of inhibition (in $\mathrm{mm}$ diameter) were read and taken as the activity against the test pathogen.

\section{RESULTS}

A good number of isolates were obtained from the different soil samples collected. 172 isolates were obtained from sample collected from Loktak Lake (LS1). 39 (AML), 25 (KC1), 101 (N3AH, N3S, NH1), 120 (NRB1, NRP1, NRS1), 46 (SJ) and 66 (SL) isolates were obtained from the soil samples of Amamlok Hills, Khangkhui cave, Nambul river, Ningel salt springs, Shirui Jungle and Shirui Lily Hills respectively. In the lake sample isolated using Chitin Agar (LSCH), we could get 35 isolates (Table 1).
Table 1: Actinomycete isolates from various niche habitats

\begin{tabular}{lll}
\hline Sample/collection site & No. of strain & Designation \\
\hline Amamlok forest & 39 & AML \\
Khangkhui cave & 25 & KC1 \\
Loktak sediments & $172 / 35$ & LS1/LSCH \\
Nambul river bank/ & $48 / 40 / 32$ & NRB1/NRP1/NRS1 \\
plant deposit/sediment & & \\
Ningel salt spring & $68 / 29 / 20$ & NH1/N3S/N3AH \\
Shirui jungle & 46 & SJ \\
Shirui lily hill & 66 & SL
\end{tabular}

Table 2: List of bioactive actinomycetes from various habitats

\begin{tabular}{lcc}
\hline Strain designation & $\begin{array}{l}\text { No. of strain } \\
\text { screened }\end{array}$ & $\begin{array}{l}\text { No. of } \\
\text { bioactive strain }\end{array}$ \\
\hline KC1 & 7 & 2 \\
LS1/LSCH & 36 & 12 \\
NRB1/NRP1/NRS1 & 28 & 12 \\
NH1/N3S/N3AH & 16 & 7 \\
SJ/SL & 12 & 4 \\
\hline
\end{tabular}

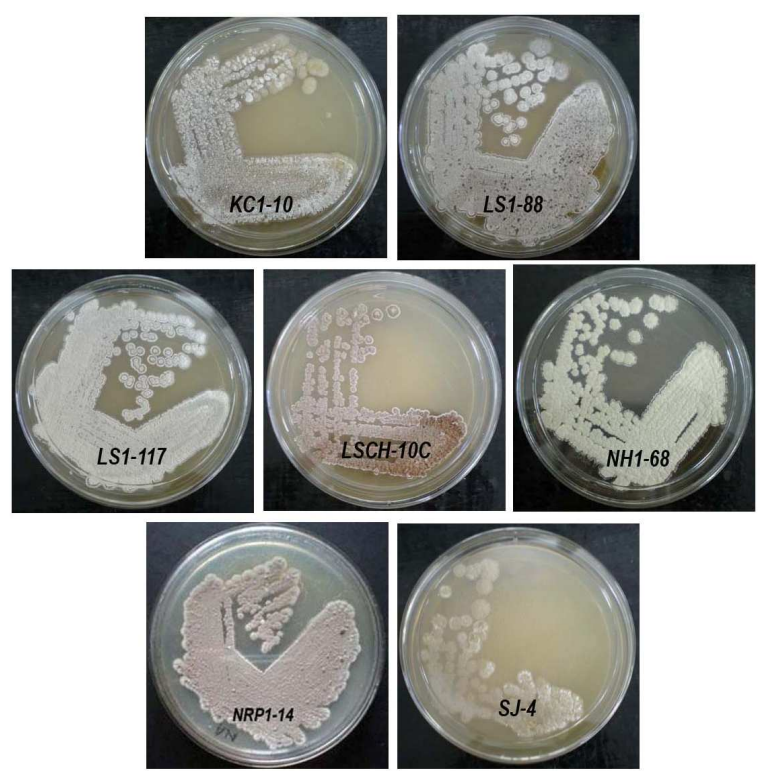

Fig. 1: Some of the bioactive actinomycete isolates from the various niche habitats of Manipur

Of the 99 isolates screened so far, 37 of them show antimicrobial activity against one or more of the test pathogens (Table 2). Of these, 32 isolates showed good antimicrobial activity against the Gram-positive bacteria, mostly against $B$. subtilis MTCC 121, 8 against Gram-negative organisms and 10 against Yeast/Fungi, with 3 showing broad spectrum of activity. Some of the representative bioactive strains are shown in Fig. 1 and 2. The antimicrobial profiles of selected actinomycete isolates are shown in Table 3. 
Am. J. Biochem. \& Biotech., 5 (4): 221-225, 2009

Table 3: Antimicrobial profile of selected actinomycetes isolates

Inhibition zone (mm)

\begin{tabular}{|c|c|c|c|c|c|c|c|}
\hline \multirow[b]{3}{*}{ Test isolates } & \multicolumn{7}{|c|}{ Test organisms } \\
\hline & \multicolumn{3}{|c|}{ Gram positive bacteria } & \multicolumn{2}{|c|}{ Gram negative bacteria } & \multicolumn{2}{|l|}{ Yeast/fungi } \\
\hline & MTCC 96 & MTCC 106 & MTCC 121 & MTCC 739 & $\mathrm{DN} 1 *$ & MTCC 227 & MTCC 1344 \\
\hline KC1-7 & - & 13 & 16 & - & - & - & - \\
\hline KC1-10 & - & 14 & 11 & 15 & - & 13 & - \\
\hline LS1-11 & - & - & 22 & - & - & - & - \\
\hline LS1-81 & - & - & 17 & - & - & - & - \\
\hline LS1-88 & - & - & 21 & - & - & - & - \\
\hline LS1-117 & 21 & 16 & 13 & - & - & - & - \\
\hline LS1-145 & - & - & 12 & - & - & - & - \\
\hline LS1-172 & - & - & 21 & - & - & 13 & - \\
\hline LSCH-2 & - & - & 18 & - & - & - & - \\
\hline LSCH-8 & - & - & - & - & - & 11 & - \\
\hline LSCH-10C & 24 & 23 & 12 & - & - & 12 & 13 \\
\hline LSCH-11A & - & - & 21 & - & - & - & - \\
\hline LSCH-23 & - & - & - & - & 11 & - & - \\
\hline LSCH-31 & 23 & 18 & - & - & - & - & - \\
\hline N3AH-18 & - & - & - & 14 & - & - & - \\
\hline N3S-27 & - & 15 & 21 & - & - & - & - \\
\hline N3S-29 & - & - & - & 12 & - & - & 14 \\
\hline NH1-2 & - & - & 15 & - & - & - & - \\
\hline NH1-11 & - & 16 & 18 & 13 & - & 11 & 13 \\
\hline NH1-28 & - & 20 & 21 & - & - & - & 11 \\
\hline NH1-68 & - & - & 22 & - & - & - & - \\
\hline NRB1-1 & 13 & - & 17 & - & - & - & - \\
\hline NRB1-9 & - & - & 21 & - & - & - & - \\
\hline NRB 1-20 & - & - & 13 & - & - & - & - \\
\hline NRB1-25 & - & - & 18 & - & - & - & - \\
\hline NRB1-33 & - & - & 21 & - & - & - & - \\
\hline NRP1-13 & - & - & 13 & - & - & - & 20 \\
\hline NRP1-14 & - & - & - & - & - & 19 & 22 \\
\hline NRP1-20 & - & - & 15 & - & - & - & - \\
\hline NRP1-28 & - & - & 17 & - & - & - & - \\
\hline NRP1-29 & - & - & 13 & - & - & - & - \\
\hline NRP1-34 & - & - & 17 & - & - & - & - \\
\hline NRP1-40 & - & - & 13 & - & - & - & - \\
\hline SJ-4 & - & - & 15 & - & - & - & - \\
\hline SJ-26 & - & - & 16 & 16 & - & - & - \\
\hline SL-7 & - & 13 & - & 14 & - & 12 & - \\
\hline SL-42 & - & 12 & 18 & 18 & - & - & - \\
\hline
\end{tabular}

Pseudomonas aeruginosa (lab isolate); MTCC 227 Candida albicans MTCC 1344 Aspergillus niger
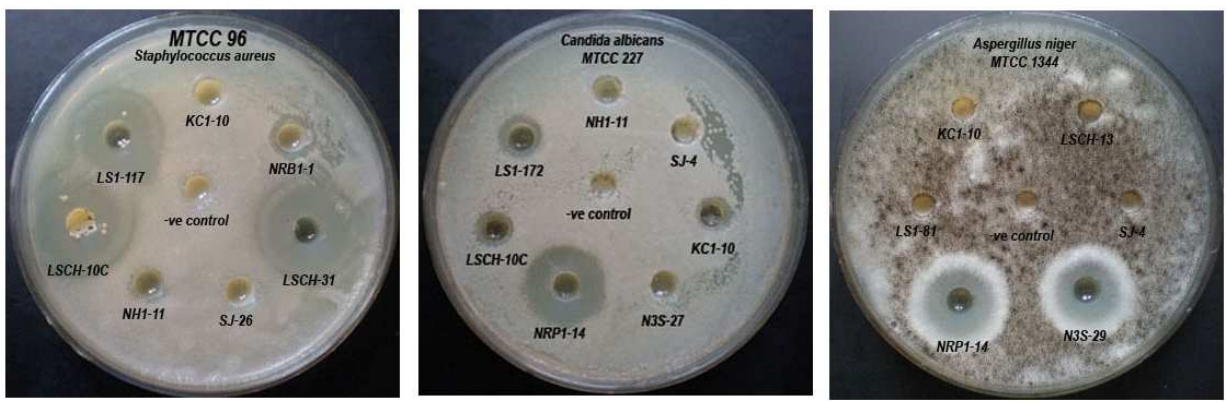

Fig. 2: Antimicrobial activity against Staphylococcus aureus MTCC 96, Candida albicans MTCC 227 and Aspergillus niger MTCC 1344 shown by selected actinomycete isolates (Kirby Bauer method)

Among these bioactive isolates, LS1-11, LS1-88, LS1-117, LS1-172, LSCH-2, LSCH-10C, LSCH-11A, LSCH-31， N3S-27， NH1-11， NH1-28， NH1-68, NRB1-9, NRB1-25, NRB1-33, NRP1-13, NRP1-14 and SL-42 show inhibition zone of $18 \mathrm{~mm}$ or above.
LSCH-23 is the only isolate showing activity against Pseudomonas aeruginosa DN1. NRP1-14 showed activity only against Yeast/Fungi. The isolate exhibiting broad spectrum of activity are KC1-10, NH1-11 and SL-7. 


\section{DISCUSSION}

Actinomycetes have been intensively surveyed in several un- and underexplored environments, niche or extreme habitats in various parts of the world in the last few decades. Wang et $a l .{ }^{[19]}$ investigated the actinomycete diversity in the rainforests of Singapore. 36 actinomycete genera were obtained, among which Streptomyces, Micromonospora, Actinoplanes, Actinomadura, Nonomuria, Nocardia and Streptosporangium were the most abundant. Actinomycete diversity has been extensively studied in China by several groups esp. from unexplored or niche habitats. Novel strains, species and even genera have been discovered in the last few decades ${ }^{[20]}$. Similarly actinomycete diversity esp. entophytic actinomycetes have been surveyed in Thailand ${ }^{[21]}$, in Jordan ${ }^{[22]}$, in Egypt $^{[23]}$.

Several unusual or niche habitats have been explored for bioactive actinomycetes. For example interesting strains have been isolated from cave environments ${ }^{[24]}$; salt pans and other salty ecosystems. Of late, aquatic environments have yielded interesting strains and even novel genera such as Salinispora and Verrucosispora etc from which new antibiotics such as salinisporamides and abyssomycins were obtained ${ }^{[25]}$. We have found in this study that niche habitats in Manipur esp. wetlands are promising sources of bioactive actinomycetes. In contrast with marine environment, freshwater sources have been less explored. Among the potent antimicrobial isolates, several were strains isolated from Loktak and Nambul (LS1, NRB1 and NRP1 series). Bioactive actinomycetes have been reported from Lake Baikal in Russia $^{[26]}$, Nile river in Egypt ${ }^{[27]}$, Krishna river in Andhra Pradesh, India ${ }^{[28]}$. Interestingly besides Streptomyces we found several nocardioform actinomycetes from wetlands in Manipur esp. Loktak lake sediments. This result contrasts with that of Terkina $e t$ al. ${ }^{[26]}$ where majority of water isolates were Streptomyces and sediment isolates were predominantly Micromonospora. But in their case, Baikal is oligotrophic lake whereas Loktak is highly eutrophic due to polluted rivers flowing into it and anthropogenic activities around the lake. Prevalence of nocardioforms in freshwater habitats with possible linkage with anthropogenic activities were reported by Rowbotham et $a l .{ }^{[29]}$ in England and Yamamura et al. ${ }^{[30]}$ for moat sediment actinomycetes in Japan. Further studies on actinomycete population in the plethora of wetlands in Manipur-lakes, rivers, ponds, marshes etc.-hold promise for novel strains or even species of bioactive actinomycetes. We are targeting our further investigations to cover more wetlands in Manipur using diverse selective media and pretreatment methods.

\section{CONCLUSION}

That Manipur is a goldmine of biodiversity has been amply justified by the richness of her floral and faunal diversity and now also microbial diversity. Our studies will establish the rich actinomycete diversity of the region, especially the various niche habitats of Manipur and also help conserve and utilize them in bioindustry. Further intensive studies on the actinobacterial diversity of unique biotopes in Manipur should form an important input into Indian biotech industry.

\section{REFERENCES}

1. MTCC, 1998. Actinomycetes: Isolation, Screening, Identification and Gene Cloning in StreptomycesLaboratory Manual. MTCC, IMTECH, Chandigarh, pp: 94.

2. Atlas, R.M., 1997. Handbook of Microbiological Media. CRC Press, Inc., USA., ISBN: 0-84931818-1.

3. Bauer, A.W., W.M.M. Kirby, J.C. Sherris and M. Truck, 1966. Antibiotic susceptibility testing by a standardized single disk method. Am. J. Clin. Pathol., 45: 493-496. PMID: 5325707

4. Bull, A.T., A.C. Ward and M. Goodfellow, 2000. Search and discovery strategies for biotechnology: The paradigm shift. Microbiol. Mol. Biol. Rev., 64: 573-606. PMID: 10974127

5. El-Nakeeb, M.A. and H.A. Lechevalier, 1963. Selective isolation of aerobic actinomycetes. Applied Microbiol., 11: 75-77. PMID: 13937509

6. Goodfellow, M., S.T. Williams and M. Mordarski, 1988. Actinomycetes in Biotechnology. Academic Press, London.

7. Hsu, S.C. and J.L. Lockwood, 1975. Powdered chitin agar as a selective medium for enumeration of actinomycetes in water and soil. Applied Environ. Microbiol., 29: 422-426.

8. Kuster, E. and S.T. Williams, 1964. Selection of media for isolation of streptomycetes. Nature, 202: 928-929. PMID: 14190108

9. Lam, K.S., 2006. Discovery of novel metabolites from marine actinomycetes. Curr. Opin. Microbiol., 9: 245-251. PMID: 16675289

10. Monreal, J. and E.T. Reese, 1969. The chitinase of Serratia marcescens. Can. J. Microbiol., 15: 689-696. PMID: 4894282 
11. Ndonde, M.J.M. and E. Semu, 2000. Preliminary characterization of some Streptomyces species from four Tanzanian soils and their antimicrobial potential against selected plant and animal pathogenic bacteria. World J. Microbiol. Biotechnol., 16 : 595-599. DOI: 10.1023/A:1008916418258

12. Sacramento, D.R., R.R.R. Coelho, M.D. Wigg, L.F. de Toledo and M.G.M. dos Santos et al., 2004. Antimicrobial and antiviral activities of an actinomycete (Streptomyces sp.) isolated from a Brazilian tropical forest soil. World J. Microbiol. Biotechnol., 20: 225-229. DOI: 10.1023/B:WIBI.0000023824.20673.2f

13. Saadoun, I., F. Al-Momani, H.I. Malkani and M.J. Mohammad, 1999. Isolation, Identification and analysis of antibacterial activity of soil streptomycetes isolates from North Jordan. Microbios, 100: 41-46. PMID: 10582379

14. Saadoun, I. and R. Gharaibeh, 2003. The Streptomyces flora of Badia region of Jordan and its potential as a source of antibiotics active against antibiotic-resistant bacteria. J. Arid Environ., 53: 365-371. DOI: 10.1006/jare.2002.1053

15. Myers, N., R.A. Mittermeier, C.G. Mittermeier, G.A.B. Da Fonseca and J. Kent, 2000. Biodiversity hotsopts for conservation priorities. Nature, 403: 853-858. PMID: 10706275

16. Ningthoujam, D.S., S. Sanasam, S. Nimaichand, and P. Sanjenbam, 2009. Screening and optimization studies of native anticandidal actinomycetes from Manipur (Indo-Burma Biodiversity Hotspot), India. Proceeding of the 15th International Symposium on the Biology of Actinomycetes Aug. 20-25, Shanghai Jiaotong University, Shanghai.

http://www.isba15.org/pdf/ISBA15_Handbook_09 0816.pdf

17. Williams, S.T., M. Sharmeemullah, E.T. Watson and C.I. Mayfield, 1972. Studies on the ecology of actinomycetes in soil VI. The influence of moisture tension on growth and survival. Soil Biol. Biochem., 4: 215-225.

18. Williams, S.T., 1971. Actinomycetes. Methods Microbiol., 4: 295-334.

19. Wang, Y., Z.S. Zhang, J.S. Ruan, Y.M. Wang and S.M. Ali, 1999. Investigation of actinomycete diversity in the tropical rainforests of Singapore. J. Ind. Microbiol. Biotechnol., 23: 178-187.
20. Xu, L.H., Q.R. Li and C.L. Jiang, 1996. Diversity of soil actinomycetes in Yunnan, China. Applied Environ. Microbiol., 62: 244-248. PMID: 16535212

21. Taechowisan, T., J.F. Peberdy and S. Lumyong, 2003. Chitinase production by endophytic Streptomyces aureofaciens CMUAc130 and its antagonism against phytopathogenic fungi. Ann. Microbiol., 53: 447-461.

22. Saadoun, I. and R. Gharaibeh, 2003. The Streptomyces flora of Badia region of Jordan and its potential as a source of antibiotics against antibiotic-resistant bacteria. J. Arid Environ., 53: 365-371. DOI: 10.1006/jare.2002.1043

23. Atta, H.M., 2009. An antifungal agent produced by Streptomyces olivaceiscleroticus AZ-SH514. World Applied Sci. J., 6: 1495-1505. http://idosi.org/wasj/wasj6(11)/7/pdf

24. Groth I., P. Schumann, B. Schuetze, K. Augsten and E. Stackebrandt, 2002. Knoellia sinensis gen. nov., sp. nov. and Knoellia subterranea sp. nov., two novel actinobacteria isolated from a cave. Int. J. Syst. Evol. Microbiol. 52, 77-84.

25. Jensen, P.R., R. Dwight and W. Fenical, 1991. Distribution of actinomycetes in near-shore tropical marine sediments. Applied Environ. Microbiol. 57: 1102-1108. PMID: 2059035

26. Terkina, I.A., V.V. Parfenova and T.S. Ahn, 2006. Antagonistic activity of actinomycetes of Lake Baikal. Applied Biochem. Microbiol. 42: 173-176. PMID: 16761573

27. Rifaat, H.M., 2003. The biodiversity of actinomycetes in the river Nile exhibiting antifungal activity. J. Mediterranean Ecol., 4: 5-7. http://www.jmecology.com/pdf/2003/34/01rifaat.pdf

28. Elliah, P., K.V.V. Raju, S.N. Bapi, K. Adinarayana and G. Adinarayana et al., 2002. Bioactive actinomycets from Krishna river sediments of Andhra Pradesh. Hindusthan Antibiot. Bull., 44: 1-4. PMID: 15061588

29. Rowbotham, T.J. and T. Cross, 1977. Ecology of Rhodococcus coprophilus and associated actinomycets in fresh water and agricultural habitats. J. Gen. Microbiol., 100: 231-240. DOI: 10.1099/00221287-100-2-23

30. Yamamura, H., M. Hayakawa, Y. Nakagawa and Y. Iimura, 2003. Species diversity of nocardiae isolated from lake and moat sediment samples. Actinomycetology, $\quad 17$ : 44-46. $\quad$ DOI: 10.3209/saj.17_44 